\title{
Mucin 遺伝子と臨床免疫学
}

\author{
今 井浩 三・日野田裕治・高橋徹
}

Jpn. J. Clin. Immun., 17 (3) : 139 146, 1994.

I 、はじめに

上皮細胞の分泌する粘液の主成分であるムチンは， 近年分子生物学的手法によって次々にコア蛋白の cDNA が得られ，その共通する構造や特徽が次第に 明らかにされてきたすすなわち MUC 1-MUC7の cDNA がクローニングされ，MUC1kついてはその 機能を含めて極めて注目すべき新しい展開がみられる ようになった。ここではわれわれの成績を含めて現状 を述べてみたい。

\section{Mucin コア蛋白の構造}

Mucin コア蛋白のcDNAクローニングは, mucin 分子を認識するモノクローナル抗体 (MoAb) を用い てスクリーニングする方法により行われた ${ }^{1,22}$. その 結果, 得られたムチンコア蛋白 cDNA は，60 塩基の 繰返し配列（tandem repeat）を示した. 1980 年代 に，われわれも含めて多くのグループがムチン分子上 の腫場関連抗原を認識する MoAbを作製したが，こ
れらの MoAb は，ほほ例外なく同一の抗体でサンド イッチアッセイを組むことが可能であり，エピトープ が分子上で繰り返しているとしか考えられなかった。 その意味でも，最初に発表された塩基配列は極めて印 象的であった。

この分子はさらにクローニングが進められ，1990 年にはその 1 次構造が明らかとなった ${ }^{3)}$. 図 1 にドメ インモデルを示すが，20アミノ酸よりなる繰返しド メインを約 40 有する巨大な膜貫通蛋白である。この ムチン分子は, 現在では MUC 1 と呼ばれる。マウス のMUC 1 ホモローグもとられている゙)が，興味深い ことに tandem repeat 領域では，アミノ酸レベルで ヒトとの間に $34 \%$ のホモロジーしかないのに対し， 膜貫通ドメインと細胞質内ドメインでは $87 \%$ と高い 類似性を示した。また mRNA のレベルでは, alternative splicing によって膜貫通ドメインと細胞質内ド メインを欠く分泌型のものが得られている3゙が，まだ 蛋白レベルでの証明はなされていない.

次いで 1991 年に MUC 2 の 1 次構造がほほ明らか

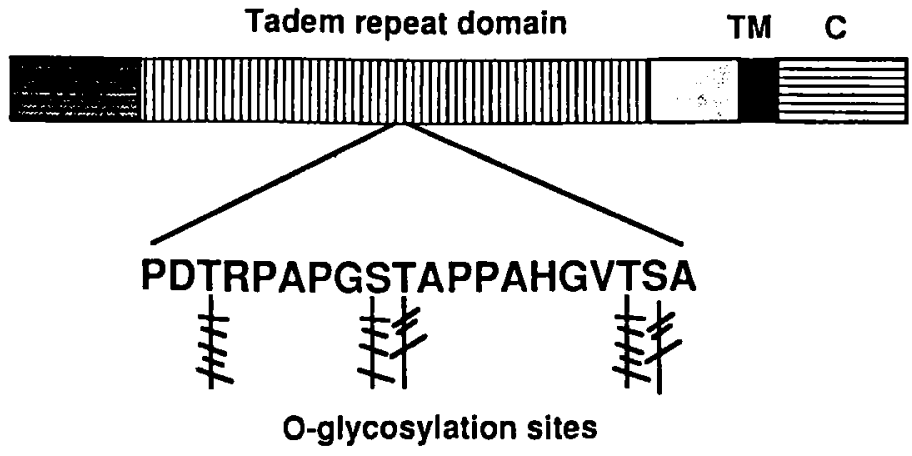

図 1 A domain model of MUC 1-glycoprotein

札幌医科大学第 1 内科 


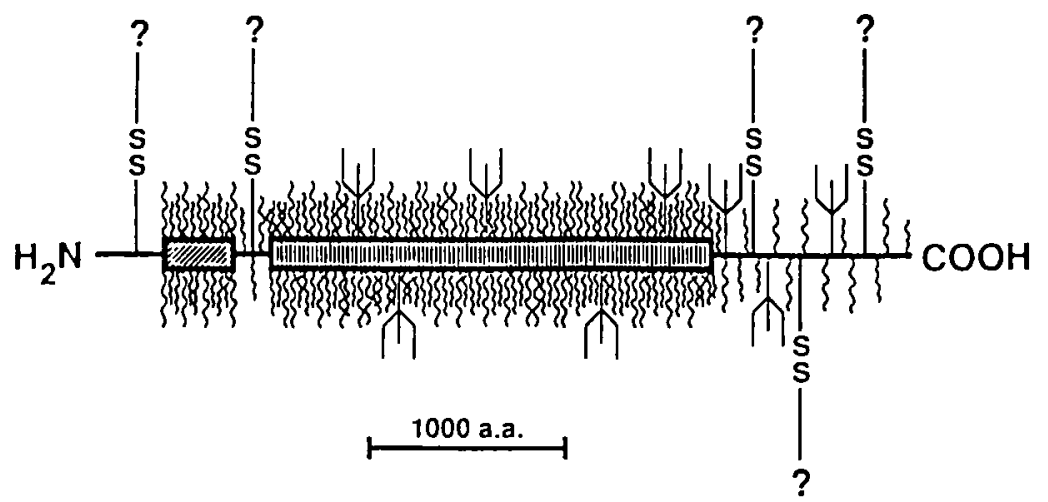

Repeat domain : PTTTPITTTTTVTPTPTPTGTQT

図 2 Current model of MUC 2 glycoprotein structure (Kim et al., 1991)

表 1 ヒトムチンコア蛋白 MUC 1-6

\begin{tabular}{|c|c|c|c|}
\hline Gene & $\begin{array}{l}\text { No. amino } \\
\text { acids of } \\
\text { tandem } \\
\text { repeat }\end{array}$ & Tissue distribution & $\begin{array}{l}\text { Chromosoma } \\
\text { localization }\end{array}$ \\
\hline MUC 1 & 20 & wide & $1 \mathrm{q} 21$ \\
\hline MUC 2 & 23 & intestine & $11 \mathrm{p} 15$ \\
\hline MUC 3 & 17 & intestine & 7 q 22 \\
\hline MUC 4 & 16 & trachea, colon & 3 q 29 \\
\hline MUC 5 & 8 & trachea & $11 \mathrm{p} 15$ \\
\hline MUC 6 & 169 & stomach, intestine & $11 \mathrm{p} 15$ \\
\hline MUC 7 & 23 & salivary gland & n.d. \\
\hline
\end{tabular}

*現在知られている主なもののみ記す。

にされた5). ヒト大腸癌細胞株ムチンの糖鎖部分を除 去してポリクローナル抗体を得，これを用いて空腸の ライブラリーをスクリーニングして cDNA を単離し た. 図 2 にドメインモデルを示すが, MUC 1 と同様 多数の繰返しドメインを含み, one repeat は23アミ ノ酸よりなり，極めてスレオニンに富んでいる。これ までのところ，膜貫通ドメインは証明されず分泌型の 蛋白と考えられる，遊離の SH 基を有して扔り，以前 より知られているジスルフィド結合を介して会合し, ゲル状を呈するムチンの1つであろう。

現在, ムチンコア蛋白の cDNA クローニングはさ らに進行中であり, MUC 3〜7の 5 種のコア蛋白 repeat domain の一部の塩基配列が明らかにされてい る 6 9). 表 1 に示すように, 各遺伝子の染色体に扔け る局在も知られ, MUC 2, 5，6が $11 \mathrm{p} 15$ に集中し ている点は注目される。組織分布については, MUC 1 以外はいまだ十分な検討がなされていない。 MCU 1 は乳癌細胞に対するMoAb でクローニングさ
れたが，その組織分布は極めて広くあらする臟器に 及ぶといっても過言ではない。

ヒト以外でも，ブ夕買下腺ムチン，カエルのムチン の構造も明らかにされている10!，ヒトのムチンとの間 にホモロジーは見いだされていないが, repeat domain を有する点は同一であり，ムチンコア蛋白の 共通特徴と考えられる. Eckhardt ら ${ }^{11}$ は図 3 のよう なムチン分子のモデルを示し，多数の糖鎖結合部位に 加光, tandem repeat 領域はほとんど 2 次構造をとら ずほほほ直線的な形状をとるとしている。

\section{III. 腫瘍関連抗原としての MCU 1}

MUC 1 の cDNA クローニングは乳癌細胞に対する MoAb（DF 3，HMFG 1 など）を用いて行われ，こ れらのエピトープが repeat domainのペプチド部分 に存在することを証明する結果となった.クローニン グが行われる以前から，いくつかのラボでまったく異 なる免疫原で作られた MoAbの1群が互いに類似し た反応特異性を示すことはすでに知られており ${ }^{12)}$, DF 3，HMFG 1 もこの仲間であった。このため, MUC1の 1 次構造が明らかになると, repeat domainの合成ペプチドを用いて,これら 1 群の $\mathrm{MoAb}$ のエピトープマッピングが行われることとな った ${ }^{13)}$.その結果, 図 1 のアミノ酸配列に示す PDTRP 配列の領域が, これらの MoAbにほほ共通 したエピトープであることが明らかとなった。

われわれの教室で, 胃癌患者腹水を免疫原として作 製した MoAb MUSE 11 も, 合成ぺプチドを用いた 検討から，この1群の MoAbの 1 つであることが明 らかになった ${ }^{14)}$. MUSE 11 も含めてこれらの MoAb 


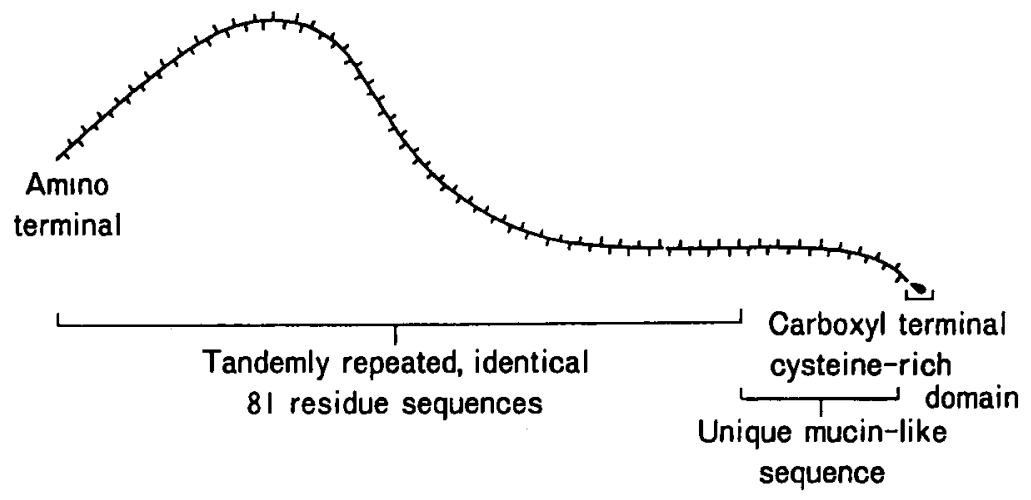

图 3 A model of the structure of porcine submaxillary mucin The bars perpendicular to the polypeptide represent $O$-linked oligosaccarides (Eckhardt, A.E. et al. : J. Biol. Chem., $266: 9678,1991$ ).

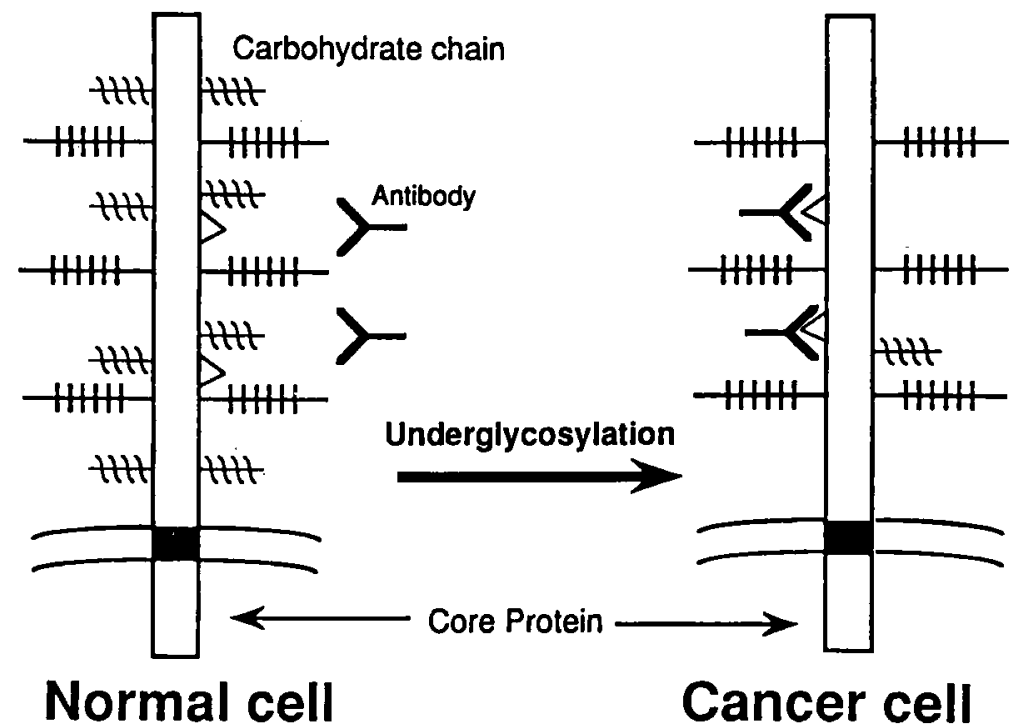

図 4 MUC 1 分子上の腫瘍性 epitope $の$ 表出

は, 腺癌関連抗原を検出する抗体として開発された が, 細胞の癌化によって, 糖鎖の形成不全の起こるこ とが知られ ${ }^{13)}$, MUC 1 ペプチドエピトープが癌細胞 に括いて露出することが, 本エピトープを腫場関連抗 原たらしめていることも明らかとなった（図 4).し かし，ここで重要なことは，これらの MoAbが合成 ペプチドではなく，糖鎖の付加された native の分子 を免疫原として作製された点である.すなわち, 各々 のエピトープはペプチド部分に加え, セリンあるいは スレオニン残基に結合した糖鎖の一部を含むため，互 いに微妙に異なる反応特異性を示す. MUSE 11 と DF 3 は互いに競合阻害を示し, 類似したエピトープ
を認識すると考えられる ${ }^{15)}$.またノイラミニダーゼに 対する感受性はDF 3 エピトープのほうが MUSE 11 エピトープに比較しはるかに強い(15).両者を比較する と, MUSE 11 が広く腺癌全般と反応する(16)のに対 し，DF 3 は乳癌，卵宩癌とはよく反応するが，胃癌， 大腸癌とはほとんど反応しない2 ${ }^{17)}$. CA 15-3 は MoAb 115 D 8 と DF 3 を用いて乳癌に特異性の高い 抗原を検出し広く臨床応用されている. $115 \mathrm{D} 8$ は DF 3 と交叉反応性を示す. 膵癌, 大腸癌などの血清 35 例を, MUSE 11 と CA 15-3で同時測定したとこ 3, MUSE $11(+)$ CA 15-3(+) 8 例, MUSE11( + ) CA 15-3(-) 10 例, 
MUSE $11(-)$ CA 15-3（+）2例であり，互いに cross-reactive な抗体であっても，それらの反応性は 異なり，それによって異なる臨床的意義を生ずる 1 つ の例と考えられた ${ }^{15}$.

ムチン分子上には，MUC1ペプチドエピトープ以 外に，いくつかの腫場関連糖鎖抗原が同定されてい る. CA 19-9, DU-PAN-2 はその代表例であるが, これらの糖鎖エピトープが MUC 1 上に発現している ことが明らかにされた ${ }^{18,19)}$.また腫湯関連抗原ではな いが, 大腸のスルホムチンのコア蛋白は MUC 2 であ ることが示された ${ }^{20)}$.このように, ムチンコア蛋白と 糖鎖抗原との関連も，今後しだいに明らかにされるも のと思われる。

\section{IV， MUC 1 反応性 CTL}

HLA 拘束を受けずに直接腫漡性の MUC 1 分子を 認識して, 乳癌や脺癌を破壊するCTLが，乳癌や膵 癌患者の “tumor-draining lymph node” 功得られ たリンパ球から誘導されうることが, Finnらのグル 一プにより報告された ${ }^{21,22)}$. そこで，われわれは，骨 髄腫細胞も MUC 1 を強く発現するので, 骨髄腫細胞 上の MUC 1 にもこのような CTLによって認識され るエピトープが存在し, 患者の細胞性免疫を誘導する 可能性はないかと考えた。

骨髄細胞中の約 7 割が骨䯣腫細胞によって占めら れ，血清中の MUSE 11 抗原価が著しい高值を示した 患者の末梢血リンパ球を用いて，同種の mixed leukocyte tumor cell culture (MLTC) を施行した。す なわちリンパ球を低濃度 rIL-2 の存在下で， 7 日ごと にMMC 処理した MUSE 11 陽性の乳癌細胞株 SKBR-3，MDA-MB-231，MDA-MB-453 おゔび骨髄 腫細胞株 PRMI 8226 で交互に刺激した。 HLA 拘束 性の同種の CTL の誘導を避けるために, 同一の練胞 株での刺激は行わなかった。培養開始後 2 週目䫉より リンパ球は非常によく増殖し, CTL line TN が確立 された。

TN の表面マーカーは CD 3, CD 8， $\alpha \beta$ TCR 陽性 で, $\gamma \delta$ TCR 陰性の典型的な CTL の phenotype を示 した，NK 細胞のマーカーである，CD 16，CD 56， CD 57 はいずれも陰性であった。

TNの各種細胞株に対する障害性を, ${ }^{51} \mathrm{Cr}$-release assay にて検討したところ，4種中 1 種の乳癌細胞 株, 6 種中 4 種の骨髄腫細胞株, 1 つの B 細胞株を非 常によく障害した（表 2 ). NK/LAK 細胞に感受性
表 2 CTL ライン TN の各種細胞株に対する 障害活性

\begin{tabular}{llr}
\hline Cell type & Tumor lines & \% Lysis \\
\hline Breast & MDA-MB-231 & 61.3 \\
& MDA-MB-453 & -4.4 \\
& SK-BR-3 & 5.9 \\
& MRK-nu 1 & 1.3 \\
Gastric & JRST & 5.4 \\
Colonic & DLD-1 & 18.3 \\
Myeloma & RPMI 8226 & 33.6 \\
& KR 4 & 63.2 \\
& KR 12 & 33.3 \\
& HO-323-8 & 46.6 \\
& TAPC & 9.4 \\
& HS-sultan & -5.3 \\
B cell & RPMI 1778 & 46.9 \\
T cell & JURKAT & 11.7 \\
& CEM & 0.5 \\
Erythroid & K 562 & 0.4 \\
\hline Fibroblast & MUC 1-trans- & 34.5 \\
& fectant & 8.1 \\
(mouse) & Mock-transfectant & 4.7 \\
\hline & Non-transfectant & \\
\hline
\end{tabular}

Effector $/$ Target $=20$

をもつK 562 はまったく障害されなかったので，TN の広い障害性は，NK/LAK 細胞の混在による，非特 異的な障害活性によるものではない．この事実は前述 した表面マーカーの結果とも一致する.

抗 $\mathrm{CD} 3$ 抗体存在下で $\mathrm{T}$ 細胞を 1 晚培養すると, TCR は “modulate”する23).この性質を利用して TN の TCR “modulate”してその障害活性を検討 してみたところ，著しい障害活性の低下を認めた。こ のCTL は標的細胞障害に TCR を用いていることが 示唆された。

TN の障害性は抗 HLA-class I 抗体によっても抗 HLA-DR 抗体によっても明らかな抑制は受けず, HLA 拘束性をもたないと考えられた.TNの広い障 害活性は HLA の偶然の一致によるものとは考えがた く，HLA 非拘束性であることをさらに裏づけるもの である．また障害性は抗 $\mathrm{CD} 4$ 抗体， $\mathrm{CD} 8$ 抗体にて も抑制されなかった。

このCTLの対応抗原をさらに明確にするために MUC 1の “transfectant”を作製した. Duke 大学の Metzger 博士より供与された MUC 1 の全長 cDNA が導入された “expression vector” ${ }^{24)}$ を，EJ-NIH- 
$3 \mathrm{~T} 3$ に導入した後 $\mathrm{G} 418$ で選別して, MUC 1 を発 現した細胞株を作製した（図 5).この細胞株の有利 な点はマウス由来であり，ヒトの細胞株と違って HLA の偶然の一致を考虑に入れる必要がない点にあ る.

この細胞株に対する障害性を検討してみたところ， MUC 1 を導入した細胞は非常によく障害されたが， “anti-sense gene" を導入した細胞やもとの EJ-NIH$3 \mathrm{~T} 3$ は障害されなかった。したがって CTLの対応 抗原はMUC 1 そのものであると考えられた。さら に，骨䯣腫細胞株である RPMI 8226 を標的として “cold target inhibition”を行い, 骨䯣腫細胞株に対 する障害性が, MUC 1 を導入した細胞によって著し

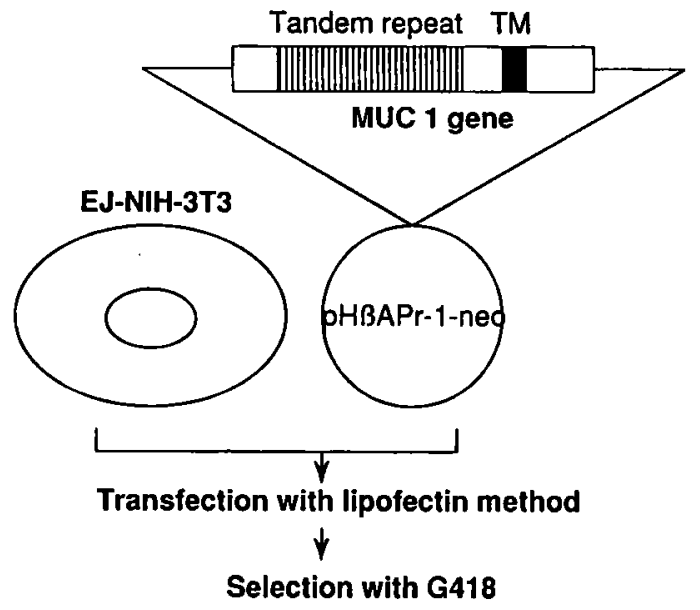

図 5 MUC 1 遺伝子導入細胞株の作製

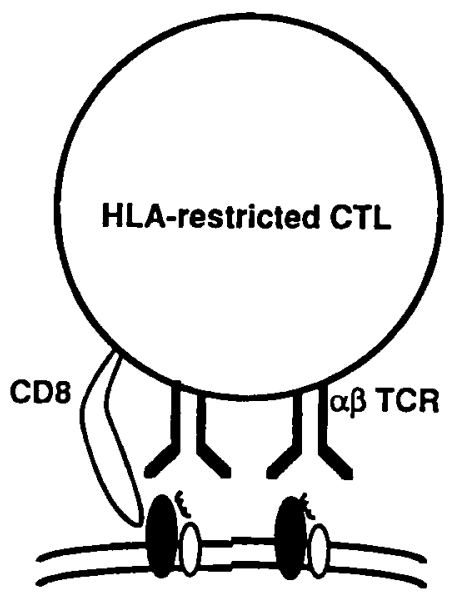

HLA CLASS I
く抑制されることを確認した。したがって骨䯣腫細胞 上にも，HLA 非拘束性 CTLによって認識される腫 瘍関連の MUC 1 エピトープが存在することが明らか となった ${ }^{25)}$.

通常の CTL は HLA 分子と, ペプチドの複合体を TCR が同時に認識するので, HLA 型の異なる細胞 に対しては，まったく障害活性を発揮することができ ない，ところがMUC1反応性 CTLは，おそらく MUC 1 分子の “tandem repeat” 上の腫瘍性エピト 一プを認識すると考えられるので HLA 拘束を受けな い. このように同一分子上で TCR の架橋現象が起こ るため，強力に T 細胞が刺激されるものと予想される (図 6). 現在までのところ $\alpha \beta$ TCR のどのような部 分が, MUC1のどこのエピトープと結合するのかは 不明である。

MUC 1 は多発性骨髄腫患者において一種の腫瘍関 連抗原としてとらえることができ，患者の細胞性免疫 によって認識される腫瘍拒絶抗原となりうる可能性が 示唆された。

自己腫瘍反応性 CTL の誘導には，自己腫瘍あるい は患者と HLA を共有する腫場細胞株が必要で，その HLA 拘束性が臨床応用の大きな障壁であった。しか し MUC 1 反応性 CTL は HLA 拘束を受けないため, 患者の HLA 型によって臨床応用の制約を受けること がない. 多発性骨髄腫の新しい治療法として, 今後 CTL 療法あるいは “live cell vaccine” による特異的 能動的免疫療法の応用が期待される. 


\section{MUC 1 に対する抗体産生}

CTLが誘導されるのであれば，抗体産生はどうで あろうか. われわれは MUC 1 repeat domain の組換 え蛋白を作製し，ウエスタンブロット法を用いてさま ざまの疾患患者血清中の抗 MUC 1 抗体を検索したと ころ，潰瘍性大腸炎において約 30\%に陽性例を見い だした ${ }^{26)}$ 。この血清の反応は，MoAb MUSE 11 によ って阻止されるため, 血中抗体のエピトープも, MUSE 11 エピトープと近似したものと考えられた。 血中の抗体はポリクローナルであろうが，エピトープ 領域が狭いために MoAb で反応が阻止されると思わ れる，最近，イタリアのグループにより卵巣癌患者り ンパ節から EB ウイルスを用いて抗 MUC 1 抗体産生 クローンが確立され，ヒト体内で抗体の産生されるこ とがさらに明確なものになった27. MUC 1 の広い組 織分布を考慮すると，多くの疾患で抗体の検出される 可能性があり，その病態に扔ける役割が注目されるこ とになろう。

カナダの Longenecker ら 28)は, MUC 1 repeat domain の合成ぺプチドを用いた免疫療法を目指して 基礎的検討を行っている. また抗 MUC $1 \mathrm{MoAb}$ の抗 イディオタイプ抗体を用いた免疫療法も検討すべきと 思わ机るしかし，このような治療法の問題点の 1 つ

1) Gendler, S., Taylor-Papadimitriou, J., Duhig, T. et al. : A highly immunogenic region of a human polymorphic epithelial mucin expressed by carcinomas is made up of tandem repeat. J. Biol. Chem., 263: 12820 12823, 1988.

2) Siddiqui, J., Abe, M., Hayes, D. et al. : Isolation and sequencing of a cDNA coding for the human DF 3 breast carcinoma-associated antigen. Proc. Natl. Acad. Sci USA, 85:2320 $\sim 2323,1988$.

3) Wreschner, D.H., Hareuveni, M., Tsarfaty, I. et al. : Human epithelial tumor antigen cDNA sequences. Eur. J. Biochem., 189: 463 $\sim 473,1990$.

4) Spicer, A.P., Parry, G., Patton, S. et al. : Molecular cloning and analysis of the mouse
として，ムチン分子自体による細胞間相互作用の阻害 がある.これまで in vitro の系ではあるが，MUC 1 が好酸球による細胞障害やCTL の反応を抑制するこ とが知られている29,30)．また sialosyl-Tn を発現した ムチンは，NK 細胞活性を抑制するとされる ${ }^{311}$ 。この 点は多種のムチンを産生する上皮性腫湯においてとり わけ重要な問題であろう。ムチンの生物学的機能の多 くは，その糖鎖部分が大きな役割を演じていると考え られ，O-グリコシド結合梼鎖の合成を阻害すること も免疫療法の一助となるのかもしれない。

\section{VI. おわりに}

ムチン分子の解析は，現在 MUC 1 が最もよく検討 され，腫瘍マーカーとしての意義だけではなく，兔疫 療法の重要なターダットとなっている．またその糖鎖 や機能の解析も進展しつつある. 今後, MUC 2-7 に 加えて，さらに多くのムチン遺伝子の発見される可能 性があり，粘液としてのイメージしかなかったムチン の構造と機能が，分子レベルで急速に解き明かされて ゆくことが予想される。

本研究は文部省科学研究費補助金重点領域研究「新 バイオがん」(今井) の補助を受けた。

homologue of the tumor-associated mucin, MUC 1, reveals conservativation of potential $\mathrm{O}$-glycosylation sites, transmembrane, and cytoplasmic domains and a loss of minisatellite-like polymorphism. J. Biol. Chem., $266: 15099 \sim 15109,1991$.

5) Toribara, N.W., Gum, J.R., Culhane, P.J. et al.: MUC-2 human small intestinal mucin gene structure. J. Clin. Invest., $88: 1005 \sim$ 1013, 1991.

6) Gum, J.R., Hicks, J.M., Swallow, D.M. et al. : Molecular cloning of cDNAs derived from a novel human intestinal mucin gene. Biochem. Biophys. Res. Commun., $171:$ 407 415, 1990.

7) Porchet, N., Cong, N.V., Dufosse, J. et al. : Molecular cloning and chromosomal localization of a novel human tracheo-bronchial 
mucin cDNA containing tandemly repeated sequences of 48 base pairs. Biochem. Biophys. Res. Commun., $175:$ 414 422, 1991.

8) Cong, N.V., Aubert, J.P., Gross, M.S. et al. : Assignment of human tracheobronchial mucin gene(s) to $11 \mathrm{p} 15$ and a tracheobronchial mucin-related sequence to chromosome 13. Hum. Genet., $86: 167 \sim 172,1990$.

9) Toribara, N.W., Roberton, A.M., Ho, S.B. et al. : Human gastric mucin. J. Biol. Chem., $268: 5879 \sim 5885,1993$.

10) Abe, M., Kufe, D.W. : Identification of a family of high molecular weight tumor-associated glycosylations. J. Immunol., $189: 257 \sim$ 261, 1987.

11) Eckhardt, A.E., Timpte, C.S., Abernethy, J.L. et al. : Porcine submaxillary mucin contains a cysteine-rich, carboxyl-terminal domain in addition to a highly repetitive, glycosylated domain. J. Biol. Chem., 266 : 9678 9686, 1991.

12) Hilkens, J., Buijs, F., Lightenberg, M. : Complexity of MAM-6, an epithelial sialomucin associated with carcinomas. Cancer Res., 49: 786〜793, 1989.

13) Burchell, J., Taylor-Papadimitriou, J., Boshell, M. et al. : A short sequence, within the amino acid tandem repeat of a cancer-associated mucin, contains immunodominant epitopes. Int. J. Cancer, 44:691 696, 1989.

14) Hinoda, Y., Nakagawa, N., Ohe, Y. et al. : Recognition of polypeptide core of mucin by monoclonal antibody MUSE 11 against an adenocarcinoma-associated antigen. Jpn. J. Cancer Res., $81:$ 1206 1209, 1990.

15) Hinoda, Y., Kakiuchi, H., Nakagawa, N. et al. : Circulating tumor-associated antigens detected by monoclonal antibodies against the polypeptide core of mucin-Comparison of antigen MUSE 11 and CA 15-3-. Gastroenterol. Jpn., $27:$ 390 395, 1992.

16) Ban, T., Imai, K., Yachi, A. : Immunological and immunochemical characterization of a novel pancreatic cancer-associated antigen
MUSE 11. Cancer Res., $49: 7141 \sim 7146,1989$.

17) Hayes, D.F., Sekine, H., Ohno, T. et al. : Use of a murine monoclonal antibody for detection of circulating plasma DF 3 antigen levels in breast cancer patients. J. Clin. Invest., 75 : 1671 1678, 1985.

18) Lan, M.S., Hollingsworth, M.A., Metzgar, R. $S$. : Polypeptide core of a human pancreatic tumor mucin antigen. Cancer Res., 50: 2997 $\sim 3001,1990$.

19) Beckstrom, D., Hansson, G.C., Nilsson, O. et al. : Purification and characterization of a membrane-bound and a secreted mucin-type glycoprotein carrying the carcinoma-associated sialyl-Le ${ }^{\mathrm{a}}$ epitope on distinct core proteins. J. Biol. Chem., 266 : 21537 21547, 1991.

20) Irimura, T., Wynn, D.M., Hager, L.G. et al. : Human colonic sulfomucin identified by a specific monoclonal antibody. Cancer Res., $51: 5728 \sim 5735,1991$.

21) Barnd, D.L., Lan, M.S., Metzger, R.S. et al. : Specific, major histocompatibility complexunrelated recognition of tumor-associated mucins by human cytotoxic $\mathrm{T}$ cells. Proc. Natl. Acad. Sci. USA, 86:7159 7163, 1989.

22) Jerome, K.R., Barnd, D.L., Bendt, K.M. et al. : Cytotoxic T-lymphocytes derived from patients with breast adenocarcinoma recog. nize an epitope present on the protein core of mucin molecule preferentially expressed by malignant cells. Cancer Res., $51: 2908 \sim 2916$, 1991.

23) Takahashi, T., Imai, Sugiyama, $T$. et al. : Preparation of anti- $\mathrm{T}$ idiotype monoclonal antibody reacting with human $\mathrm{T}$ leukemic cell lines and with a small percentage of peripheral $\mathrm{T}$ lymphocytes. Clin. Exp. Immunol., $82:$ 590 595, 1990.

24) Batra, S., Kern, H.F., Worlock, A.J. et al. : Transfection of human Muc 1 mucin gene into a poorly differentiated human pancreatic tumor cell line, Pancl : integration, expression and ultrastructural changes. Journal of 
Cell Science, 100:841 849, 1991.

25) Takahashi, T., Makiguchi, Y., Hinoda, Y. et al. : Expression of MUC 1 on myeloma cells and induction of HLA-unrestricted cytotoxic $T$ cells against MUC 1 from a multiple myeloma patient. J. Immunol., in press, 1994.

26) Hinoda, Y., Nakagawa, N., Nakamura, H. et al. : Detection of a circulating antibody against a peptide epitope on a mucin core protein, MUC 1, in ulcerative colitis. Immunol. Lett., $35: 163 \sim 168,1993$.

27) Rughetti, A., Turchi, V., Apollonj, C. et al. : Human B-cell immune response to the polymorphic epithelial mucin. Cancer Res., $53: 2457 \sim 2459,1993$.

28) Ding, L., Lalani, E., Reddish, M. et al. : Immunogenicity of synthetic peptides related to the core peptide sequence encoded by the human MUC 1 mucin gene: effect of immuni- zation on the growth of mucine mammary adenocarcinoma cells transfected with the human MUC 1 gene. Cancer Immunol. Immunother., $36: 9 \sim 17,1993$.

29) Hayes, D.F., Silberstein, D.S., Rodrique, S. W. et al. : DF 3 antigen, a human epithelial cell mucin, inhibits adhesion of eosinophils to antibody-coated targets. J. Immunol., 145 : $962 \sim 970,1990$.

30) van de Wiel-van Kemenade, E., Lightenberg, M.J., de Boer, A.J. et al. : Episialin (MUC 1) inhibits cytotoxic lymphocyte-target cell interaction. J. Immunol., 151:767〜776, 1993.

31) Ogata, S., Maimonis, P.J., Itzkowitz, S.H. et al.: Mucins bearing the cancer-associated sialosyl-Tn antigen mediate inhibition of natural killer cell cytotoxicity. Cancer Res., $52: 4741 \sim 4746,1992$. 